\title{
Beyond Masculinity: Gender, Conflict and Post-Conflict Reconstruction in Northern Uganda
}

\author{
Robert Senath Esuruku ${ }^{1}$
}

(C) Uganda Martyrs University

\begin{abstract}
Masculinity and femininity debates of armed conflict in Africa have always regarded men as fighters and women as passive victims of war. The exclusion of women from the armed forces in most traditional societies originated from the assumption that women are a weaker sex and therefore cannot manage military life. Nevertheless, women in Uganda have voluntarily joined the armed forces, while some of them have been abducted and forcefully recruited into the rebel forces. Notwithstanding the central role women have played in the armed conflict in Northern Uganda, they have been side-lined in the processes of peace negotiation and post conflict reconstruction of the region. This paper looks at how masculinity is manipulated in conflict and the role women have played in the conflict, peace process and post conflict reconstruction in Northern Uganda.
\end{abstract}

Keywords $\cdot$ Gender $\cdot$ Post-conflict reconstruction $\cdot$ Transitional justice

\section{Introduction}

The over two decades of armed conflict in Northern Uganda has inflicted immense suffering on women, men and children. It has resulted in loss of lives, and destruction of infrastructure, social services and social fibre. While the conflict has caused suffering to everyone, women and children have suffered most. Women have been sexually assaulted, maimed, abducted and forcefully recruited into the armed forces. The exploitation and victimisation of women has led to prolonged emotional trauma, unwanted pregnancies and sexual diseases including HIV/AIDS. As culturally designated caregivers, women struggle to support their families and keep their households together while their husbands, sons and daughters are caught up in the fighting and are unable to provide for the remaining family members. The new role of women as primary providers in conflict areas has often exposed many of them to further abuse by bandits outside the Internal Displaced Peoples (IDP) camps.

\footnotetext{
${ }^{1}$ Alert International, Uganda. E-mail: esuruku@nd.edu
} 
The armed conflict has completely shattered the traditional role and expectation of men as providers for their families. The responsibility to provide for the family has shifted to women while the idle and severely frustrated men have resorted to alcoholism. Many men upset by the loss of their traditional roles as providers resorted to domestic violence, suicide, abandonment and some of them ended up in acute mental illness. Women have taken the responsibility of providing for their families and they are the forerunners in advocating the end of the conflict through peaceful resolution. However, despite the diminishing masculinities inflicted by the armed conflict, which will be discussed in detail latter, both Government of Uganda (GoU) and Lord's Resistance Army (LRA) seem to regard peaceful resolution to the armed conflict unmanly. Acknowledgement, apology, forgiveness and restitution are regarded to be feminine because 'real men' are believed to resolve their differences in the battle field.

This paper provides an insight into the construction and manipulation of masculinities and women's role in the conflict, peace process and post-conflict reconstruction in Northern Uganda. The first part of the paper focuses on the construction and manipulation of masculinities and women's roles in the armed conflict. The second part of the paper looks at the masculine and feminine forces in the various attempts to solve the armed conflict and thirdly the paper addresses the transition to peace and post-conflict reconstruction. The paper then concludes that armed conflict(s) in Northern Uganda is not gender neutral. It is determined by the gendered identities of women and men, power imbalances between them and their gendered roles in armed conflict. While it is debatable whether women are more vulnerable than men in war settings, what is clear is that women are more susceptible than men to marginalisation, poverty and suffering brought about by armed conflict (Ohlsson, 2000). The fact that women are perceived as symbolic bearers of cultural and ethnic identity and producers of future generations also makes them the target of the enemy. Women's position is further undermined by the nature of the present-day armed conflicts, where the civilian population is totally caught up in the fighting forcing women to single-handedly maintain and provide for the everyday material survival of their families.

In post-conflict reconstruction period, it is important to recognise that there are aspects of women and girls experiences of armed conflict which are not shared by men and boys. Gender identity affects the ways in which people are caught up in armed conflict and what happens to them during and after it (Sweetman, 2005). As a result, lack of a gendered analysis of the impact of armed conflict, post-conflict reconstruction and peacebuilding policies ignores specific interest of women and men. Sustainable post-conflict reconstruction and peace building depend on the full and equal participation of both women and men in preserving and fostering culture of peace and development in Uganda and Northern Uganda in particular.

\section{Construction of Masculinity and Conflict}

Masculinity refers to the multiple ways in which manhood is socially defined from historical and cultural context and it is also associated with power. Masculinity generally is expressed through negative attributes such as risk-taking, physical toughness, aggression and violence. It is also expressed through positive attributes such as self-discipline, emotional control, overt heterosexual desire, protection and decisiveness. The contested 
attributes of masculinities are individualism, competitiveness, rationality and practicality. The negative features of masculinity are what subsequently results in power inequalities between individuals, social groups and institutions and the structural violence through which power inequalities are expressed (Scott-Sammuel, 2009). Martial behaviour is also traditionally associated with masculinity and its characteristics include aggression, courage, endurance and semblance of comradeship. These same qualities may be expressed negatively as cruelty, mindlessness, blind obedience and clannishness.

For many communities in sub-Saharan Africa, there are specific ceremonial processes that males undergo to symbolically make the transition into adulthood. Many of these rituals include abandoning boyhood in favour of manhood. Some of the rites include a cathartic moment of being under the control of spirits before achieving a defined and mature adult identity. Within some of the cultures, emphasis is placed on specific set of skills tied to the main source of livelihood within that culture. Some emphasise warrior skills while others focus on agricultural or herding skills, but all rites of passage in one way or the other focus on some method of provision (Dolan, 2003; Gilbert, 2006 \& Woodbury, 2011). The main social requirement for achieving manhood is attainment of some level of financial independence, employment and subsequently starting a family. In many parts of sub-Saharan Africa where bride price constitutes part of marriage, family formation is directly tied to having income or property. According to Barker and Ricardo (2005), one of the most consistent measures of manhood within sub-Saharan African is self-sufficiency and ultimately familial provision. Therefore, the failure by an adult male to provide for his family can affect his self-perception as well as communal identity. Men's social recognition and their sense of manhood suffer when they lack work and are unable to take care of their families.

Masculinity is founded on the role and responsibilities of a male member of a household or community. However, the validity of this assumption is repeatedly questioned due to dramatic cases that have resulted in the reversal of roles between women and men within a household and in their communities. Some of the changes which have been most frequently cited in recent times include the loss of economic power by males mainly drawn from among the working poor, the increase in the purchasing power of women through the spread of formal and informal income-generating activities and the emergence of female-headed households (Silberschmidt, 2007). Today, norms about manhood are constructed against the backdrop of other power hierarchies and differences in income that give greater power to some men such as middle class, professional men from certain ethnic groups or older men and exclude or dominate others such as younger boys, men from minority or disempowered ethnic groups and men with lower income (Woodbury, 2011). The power imbalance that defines gender relations influences women's access to and control over resources, their visibility and participation in social and political affairs, and their ability to realise their fundamental human rights. These developments have some implications for understanding masculinities in conflict and post-conflict reconstruction.

Masculinity is linked to conflict because the formal, relational properties of masculinity provide a framework through which conflict can be rendered both intelligible and acceptable as a social practice and institution (Hutchings, 2007). In the context of conflict, some elements of traditional masculinities such as risk taking, use of aggression and physical violence are emphasised and adjusted to support war. Frequently within cultures that have political grievance, the idea of the male struggling against a political enemy is 
glorified. They describe how this idea of masculinity is commonly elevated above traditional ideas of manhood and maleness and how the archetypal male is redefined to one involved in this kind of a political struggle. Within conflicts where political motivations are less obvious, masculine identity is revealed through struggle for power. Some armed insurgencies may have clear ideological motives, but many are directly related to an attempt by young men to acquire power, question the power of groups of older men and live up to a specific version of manhood. The worst violence seems to happen when there is a political vacuum and violence becomes an end in itself, providing young men with power, sexual partners and income (Woodbury, 2011). Masculinity is being used to fuel conflict through the pursuit of political and economic power.

Studies separately conducted by Sommers (2006) and Jacobsen (2006) established that men are generally perceived as the primary initiators of warfare and violence across subSaharan Africa. The studies further established that men commit acts of violence in far greater numbers than women. Theidon (2009) argues that to be a combatant was to be male and thus gender was not an issue. In other words, regardless of the realities of war, the term combatant and conflict in general have male undertones. Therefore, masculinity is tied to the initiation of conflict through the valuing of masculinity in a political sense and through the male struggle for power. For example, the exclusion of women from the military is also linguistically reflected in Kinyarwanda. The word for "male" is umugabo where the stem $g a b(o)$ denotes masculinity. It is therefore not surprising that the Kinyarwanda word for the army is ingabo. This same word also signifies "shield." Here, the emphasis is on the protective role played by the male soldier in the society (Gallimore, 2008).

In the context of violent conflicts, the symbolic nature of the traditional rite of passage is utilised in the context of conflict to empower males to use violence as an alternative method of achieving manhood. Masculinity is reconstructed within warfare to include the use of violence as a means to achieve power (Gallimore, 2008; Woodbury, 2011). At the most basic level, boys involved in brutal armed insurgencies become big men by being in control of a setting and being able to exert violence on those around them. Young men who are recruited into the armed forces are forced to commit horrific atrocities such as murder of friends and relatives. In northern Uganda, the LRA abducted children in record numbers and subjected them to brutal treatment as soldiers, labourers, and sexual slaves (Human Rights Watch, 2003).

Conflict provides the opportunity for alternative interpretations of masculinity, particularly in situations where traditional ideas of masculinity is under threat from lack of economic opportunity. Frustrated populations seeking alternative methods of transitioning into adulthood can find options within the context of conflict, making them prime targets for militant leadership as well as viable candidates for initiating conflict themselves.

\section{The Feminine Face of the Conflict}

Traditionally violent conflicts have been associated with men who are believed to be ordained fighters. The masculine image of brute strength, physical endurance, weapons training, unquestioning obedience, totalitarian leadership, unadulterated violence and allegiance to one's country creates an iconic male figure and leaves one questioning women's roles in violent conflict. Despite this iconic belief that the military is the domain of men, women have always been associated with the military. Women have been 
intimately connected to the military through familial relations as wives, mothers, sisters and daughters (Enloe, 2000). This connection means that women's lives are often deeply affected by military work. Beyond family members and soldiers, women's relation to the military has not always been positive or progressive. The only association many women have had with the military is that of sex slaves, comfort women and victims of sexual assault. Because of the hyper masculine nature of the military and its endeavours, soldiers are often imbued with qualities of violence, aggression and boldness, along with hyper sexuality, thus creating an environment that leads to sexual abuse (Enloe, 2000).

In the past, female family members often served companies of male soldiers in order to stay connected. They acted as cooks, laundresses, and support staff for the travelling companies of men. There are many stories that relate to women who took up arms alongside their male relatives even though they were not trained to defend themselves. "Molly Pitcher" is the name given to a composite image of women who, during the Civil War, while travelling through battlefields to help keep soldiers hydrated, dropped their water pitchers and took up arms among fallen male soldiers in order to aid in the battle. Other women donned male clothing to serve as soldiers, taking on male names and personas (Lorentzen \& Turpin, 1998). Today, women have increasingly been incorporated into armed forces worldwide both in conventional and guerrilla armies. For many years however, women's role in war and other types of violent conflict remained almost invisible throughout the world. Accounts of war tended to cast men as protectors and doers while women were portrayed as passive and innocent victims (Marlala-Routledge, 2008). As women's experiences have become more broadly known, it is clear that there are many different ways in which women participate in wars as fighters, community leaders, social organisers, workers, farmers, traders, welfare workers, among other roles (MarlalaRoutledge, 2008 \& Oywa, 2002).

Since the inception of the civil conflict in northern Uganda, women have voluntarily and forcefully been recruited into the armed forces. The most notable was Alice Auma Lakwena who led the armed group that preceded Joseph Kony's Lord's Resistance Army (LRA). Later the LRA abducted and forcefully recruited girls and women into their rebel forces. Girls who were abducted by the LRA were allocated as wives to commanders and some were used as sex slaves by the rebels (Annan et al, 2009; Mazurana et al., 2003 \& Oywa, 2002). Abducted girls who have returned home tend to show acute emotional disturbance and are often rejected by their communities and family members. Women who voluntarily joined the armed forces often did so due to hopelessness in the region and as a way of protecting themselves. Their experiences demonstrate that women have had to respond to the pressures of violence in extraordinary ways that are profoundly challenging to traditional social roles.

Women have responded to these challenges by assuming diverse roles ranging from joining the armed forces, peace negotiation and community peace building. While some commanders have ridiculed peaceful negotiation as feminine and upheld armed conflict as a masculine standard to end the armed conflicts in Northern Uganda, women have never given up with their appeal for nonviolent resolutions. In 1989, the Gulu District Women's Development Committee mobilised a peaceful demonstration wearing rags and singing funeral songs they marched through Gulu municipality demanding an end to the armed conflict. The women's committee have written several letters to the GoU, LRA leaders and the international community demanding an end to the armed conflict in Northern Uganda. They have also participated in prayers organised by the different faith 
organisations to pray for peace and they have looked after the children of their daughters and sons, nursed the injured and offered psycho social support to traumatised individuals at the family level (Oywa, 2002).

Armed conflict(s) have resulted in forced displacement of populations majority of whom were women and children. Forced displacement disrupted the wellbeing and protection of women, men and children and predisposed them to insecurity and powerlessness. For women and girls, in particular, forced migration rendered them vulnerable to sexual and gender-based violence. Many women were exposed to unwanted pregnancies and STDs including HIV/AIDS. A study conducted by the Ministry of Health $(\mathrm{MoH})$ (2007) established that women and girls were subjected to different forms of gender-based violence including abduction, gang rape, forced marriage, unwanted pregnancies, and sexual mutilation. In Pabbo, the largest IDP camp in Gulu district, sexual violence and defilement occurred on a daily basis. A study conducted in Pader district by Concern Worldwide (2008) established that the community preferred to settle cases of rape out of court and marry off the survivor to the perpetrator instead of pursuing legal redress.

Similarly, women and girls returning to Northern Uganda from LRA conscription have often suffered rejection from communities and their families. After leaving the LRA, the women return to their villages with children forcibly fathered by LRA commanders. These women have often been shunned by their families and labelled as "bush women" by their communities. Many of these women have abandoned their homes and are now living at Kasubi and Layubi sub-wards in the outskirts of Gulu municipality. Originally, guncarrying combatants, cooks, logisticians, spies, sex partners and porters for the LRA are now leading desperate lives working as prostitutes or brewing alcohol for a living (Integrated Regional Information Networks, 2011).

\section{A Case of Sexual Violence}

Sexual violence as a weapon of war directed against both women and men is well documented in academic literature (Alison, 2007; Okio, 2008 \& Romaniuk, 2010). It consists of acts rape, coerced undressing and non-penetrating sexual assault such as sexual mutilation. Rape is also used to symbolise strength, power and physical dominance. According to Alison (2007), rape in war time is intentionally committed by specific men against specific women and men namely enemy women and men. She contends that males are ascribed characteristics such as aggression and their assumed physical strength is designed to protect the female, a non-aggressive nurturer of life and thus, the masculine is elevated over the feminine. Incorporating ethnicity, Alison (2007) observed that these differences are extended during times of conflict. Not only is masculine contrasted to feminine within a group and "us" contrasted to 'them' between groups, but "our women" are contrasted to "their women" and "our men" to "their men". Masculinity is preserved for the males of the warring factions insofar as they are able to protect "their" women.

During armed conflict, rape of women serves as a demonstration of power by a group of men over the enemy women which simultaneously serve to emasculate the males of the enemy group. According to Alison (2007), masculine is dominant over the enemy female and the enemy feminised male. She further noted that the ethno-national identity of the enemy group is feminised as the rape of women symbolises the dominance of one group over another. Sexual violence is not directed towards the women of one's own group 
unless that woman is perceived as a traitor and she is associated with the enemy. According to Alison (2007) male-to-male sexual violence holds the same logic as male-tofemale sexual violence. It feminises the enemy male who experiences the violence. Since masculine sexuality is socially constructed as active while feminine sexuality is constructed as passive, the male who rapes the enemy male succeeds in asserting the perpetrator's dominant masculinity.

Sex as a military strategy was reported since the occupation of the Acholiland by the NRA (Amnesty International 1991; Dolan, 2003; Human Rights Watch, 1997; Van Acker, 2004; Nabukeera-Musoke, 2007 \& Ochieng, 2002). Powerful and heartbreaking allegations and testimonies by a number of human rights activists and ordinary people from Northern Uganda also suggest that NRA/M soldiers gang-raped Acholi men soon after they captured power in 1986. The NRA/M's revenge rape against Acholi men was widespread enough that the Acholi invented a new vocabulary, tek gungu, to describe male rape. The term literally means the way which is hard to bend (Human Rights Watch, 1997 \& Van Acker, 2004).

Many Acholi men who were victims of the NRA's sexual assault were said to have committed suicide because they have failed to come to terms with the shame of being sexually degraded in front their children and wives. The survivors of this horrific sexual act are ashamed to freely talk about it. There were allegations that the Acholi men helplessly watched their wives and daughters being raped by the NRA. These allegations corroborate with the Refugee Law Project video documentary "Gender against Men" in which there were revelations of such acts:

...they started collecting both men and women from a place called "Baa Dege" and gathered them in a school called St. Martin. They were sodomising the men and sometimes they would pick your wife while you were watching and they would dehumanise her in different ways. They would enter any house and defecate in your water pots and even your maize flour or any foodstuff they would come across.

In the same documentary, an Acholi elder was hospitalised for two months after being gang raped on nine different occasions by the government soldiers:

...Three men were bending me over many times over the course of nine days. They would just come into my compound. After stealing my goats and chickens, they would then come to sodomise me. I know they were government soldiers. During the act, [rape] they would not say anything. One of them stubbed me with the bayonet on his rifle. It's God who helped me, otherwise I would have died.

The sexual violence allegations were reported again in 1991 when the GoU launched "Operation North" which was premeditated to bring a total end to the conflict. During the operations, there were reports of arbitrary arrests and detentions and blanket cordon and search operations intended to net rebel collaborators which in the end generated resentment against the army and the government (Amnesty international 1991 \& O'Kadameri, 2002). Furthermore, studies conducted by Ochieng (2002 p 2) revealed that incidences of indecent massive sexual offenses were committed against civilians:

...Men and women were assembled together during what was called a screening exercise to flush out the rebels from the community. The men and women were then put in separate groups. Then in the evening, the NRA soldiers started sexually abusing 
the women in the compound. One woman could be forced to have sex with several NRA men and this went on for two days.

In March 1991, following a similar press report, Tiberio Atwoma Okeny, the leader of National Liberal Party (NLP) allegedly accused the NRA for deliberately spreading Acquired Immune Deficiency Syndrome (AIDS) in the Northern Uganda through homosexual rape (Amnesty International, 1991). He was detained by the NRA at Parunga and there was no official charge brought against him. Indeed the survey conducted by Ministry of Health (2005), indicated that HIV/AIDS prevalence rate in Northern Uganda is nearly twice as high as the national average. The HIV infection rate stands at $11.9 \%$ higher than the national rate of $6.4 \%$. Currently, estimates indicate that over 100,000 new infections occur annually with the majority of the new cases of infections coming from northern Uganda.

Sexual violence has also been used in armed conflict for propaganda reasons in order to demonise and dehumanise the adversary. It has continued to serve as a communication tool between male soldiers that the men on the other side are not capable of protecting "their" women. Such punishment of the enemy goes along with punishing "their assets" which in this case is their wives (Nabukeera-Musoke, 2007). Sexual violence against women in peace times is an extension of violence against women in situations of armed conflict that most often goes unpunished. Sexual violation of women and men erodes the fabric of a community. The harm inflicted by the rapists is an attack on families, tribe and culture which particularly affect women who are viewed as repositories of a community's cultural and spiritual values.

\section{Attempts to Solve the War}

In June 1987, the NRA/M government offered an amnesty for those who would abandon the armed conflict. In addition, Major General Salim Saleh had several discussions with Brigadier Odong Latek and other senior UPDA military commanders at Acholi Inn, in Gulu. This process culminated in the June 1988 Peace Treaty between the NRA/M government and the UPDA which was signed at Pece Stadium in Gulu, witnessed by the late Catholic Bishop Cipriano Kihangire. According to O'kademeri (2002), while many Acholi were not reconciled with the NRA/M government, they welcomed the agreement as a way of averting the anguish and despondency posed by the insurgency on the entire region. Following the agreement, several UPDA troops abandoned the rebellion and accepted an amnesty while others continued to fight the NRA/M government. According to Nyeko and Lucima (2002), during this period, Joseph Kony had already broken away from the UPDA and consolidated his forces, thus attracting the remnants of the UPDA who did not support the agreement.

In 1989, NRA's Col Peter Kerim waged a massive military offensive against the LRA. Although the military operations indeed weakened the LRA, Kerim was not able to secure the complete defeat desired by President Museveni. There was a reshuffle in which Col Samuel Wasswa subsequently replaced Kerim as 4th Division Commander. In 1990, Minister of State for Defence Maj. Gen. David Tinyefuza who was the NRA's chief military combat strategist was sent to Northern Uganda to accomplish a final military victory over the LRA. The four months military operations that began on 31 March 1991 
and later became known as "Operation North" left bad memories in the minds of the Acholi people. As already discussed, this was the period the Acholi women and men were sexually assaulted by the NRA soldiers who were supposed to protect them.

Between November 1993 and February 1994, Hon. Bigombe then the Minister of State for Pacification of Northern Uganda resident in Gulu, initiated a peace talk NRA/M government and LRA. Bigombe and a group of Acholi elders and religious leaders met with LRA leader Joseph Kony. A total ceasefire was declared during which the LRA were allowed to freely mix with civilians. In the January 1994 meeting, Kony insisted on comprehensive peace agreement to totally end the rebellion. He requested for a period of six months to mobilise the Acholi people and the political wing of the LRA abroad. However, President Museveni rejected the negotiations and gave the rebels seven days to assemble and surrender to the UPDF. The ultimatum issued by President Museveni marked the end of political and peace negotiations. The LRA intensified its operation in Northern Uganda and the government in return responded by stepping up its military campaign against LRA (Atkinson, 2010 \& O'Kadameri, 2002).

Although Bigombe made a significant progress in mediating between the LRA and GoU, several Acholi elders remained sceptical of her role as a woman in peace negotiation. The process suffered from the cultural biases and prejudices against her as a woman venturing in men's affairs of war (Bainomugisha \& Tumushabe 2005). Most UPDF officials who participated in the talks wanted the LRA to negotiate their surrender while Bigombe preferred a peace settlement where everybody was a winner (O'kadameri, 2002). In one of the meeting, Brigadier Mugume told LRA commander Otti-Lagony that he "thought Otti-Lagony had come to negotiate his surrender." This remark was considered by LRA as an assault on their masculinities. This view was corroborated by an Acholi elder who stated that people were sceptical of President Museveni appointing Bigombe a woman as a chief negotiator and yet there were elders who knew the history of the rebellion very well. With lack of support from elders who have been labelled to have blessed the rebellion, the peace process was not to last long (Bainomugisha \& Tumushabe, 2005).

Since 1994, the Sudan government offered sanctuary for the LRA and they were based in Southern Sudan while conducting cross border raids attacking UPDF positions and abducting children to swell their army. The LRA enjoyed the support of the Sudanese government in retaliation for the support which the GoU gave to a Sudanese rebel group, the Sudan People's Liberation Army/Movement (SPLA/M). Following two years of extreme violence in which horrendous atrocities were committed by the rebels, two Acholi elders Okot Ogoni and Lagony in 1996 obtained permission from the GoU to meet with the LRA to plead for peaceful resolution of the armed conflict. The LRA perceived the visit by the two Acholi elders as a challenge to their masculinities and responded by killing the Acholi elders. The news of the brutal death of the Acholi elders was perceived by the Acholi as the end to peaceful negations to the armed conflict. Later in 1997 the Acholi in diaspora organised Kacoke Madit peace initiative in London and later in Rome initiated by the based Catholic Peace Movement Community of Sant'Egidio with the purpose negotiating the release of the Aboke girls abducted by the LRA. The meeting between the "LRA representatives" and GoU was short lived after LRA disassociated itself from the representatives and arrested and sentenced to death James Alfred Obita who claimed to be LRA's Secretary for External Affairs and Mobilisation. The humiliated Obita was later released and since then he left the LRA. 
Following an intensive pressure from the desperate civilians from Northern Uganda, religious leaders, civil society and the Acholi Parliamentary Committee, an Amnesty bill was drafted and passed by the parliament into law in November 1999 and became operational in January 2000. Section (2) subsection (1) of the Act provides a blanket amnesty to all Ugandans who have since January $26^{\text {th }} 1986$ engaged in war or armed rebellion against the GoU to voluntarily abandon rebellion and surrender. Subsection (2) further states that all persons who will abandon armed rebellion and surrender shall not be prosecuted or subjected to any form of punishment for their participation in armed rebellion or for any crime committed in the cause of the war or armed rebellion. While the Act applies to all acts of wars and rebellions which have afflicted Uganda in recent years, it has particular importance in the Acholi situation, since it is seen as providing a powerful incentive for LRA fighters to abandon the rebellion and heinous atrocities against civilians.

The GoU extended an amnesty to the LRA and offices were opened in Gulu and Kitgum district. A number of peace activists in and around Gulu got involved in encouraging the LRA to abandon the rebellion against the GoU. The Comboni missionaries' Fr Tarcisio Pazzaglia and Fr Carlos Rodriguez together with Acholi cultural leaders Rwot Oywak Ywakamoi and Rwot William Lugai met with LRA commanders at different times at Pajule to pass the message that amnesty will be granted to LRA fighters who will abandon armed rebellion. Later in the year, a meeting between Lt. Col Walter Ochora, UPDF captain Oyet Waliki and LRA commander Onen Kamdulu took place at Awornyim and a demilitarised zone was created in Gulu to facilitate dialogue with the LRA. However, these initiatives did not bring peace to northern Uganda because of LRA'S perception that real men do not surrender, but fight on till the end.

In 1999, the Carter Centre facilitated a peace talk between Uganda and Sudan which resulted in the normalisation of relationships between the two countries. The governments of Sudan and Uganda entered into an agreement to cease support for each other's rebel groups and strengthened diplomatic relations and exchanged ambassadors in 2001. In March 2002, the government of Sudan allowed the Ugandan government to conduct a limited military operation inside southern Sudan known as "Operation Iron Fist." The GoU sent up to 10,000 UPDF troops to totally defeat the LRA from their bases in southern Sudan. The operation inflicted heavy casualties on the LRA forcing them to flee into the Imatong Mountains in Sudan while some of them crossed back into Uganda. In June 2002, the LRA launched a deadly fight targeting religious leaders and civilians which extended from Acholi to Lango and Teso sub regions. The LRA raided villages killing hundreds of civilians, destroying property and abducting thousands of children to increase their army.

In response to the LRA attacks, the GoU forcefully rounded up civilian from Kitgum, Lango and Teso and moved them to protected villages. The appalling situation forced the Catholic Archbishop of Gulu, John Baptist Odama and the retired Anglican Bishop of Kitgum, Baker Ochola to request President Museveni to grant them permission to meet with the rebels to seek for a peaceful solution to the armed conflict. The religious leaders mediated between GoU and the LRA during which there was exchange of letters between President Museveni and the LRA. President Museveni made proposals for safe assembly zones and ceasefire and appointed a Presidential Peace Team (PPT) to meet with the LRA. The dialogue between the religious leaders, PPT and the rebels continued. On $2^{\text {nd }}$ March, 2003, Joseph Kony declared a unilateral ceasefire and asked for direct negotiation with the government representatives, but LRA fighters violated the declaration in the following 
days killing and abducting civilians. On $6^{\text {th }}$ March, 2003 President Museveni declared a limited ceasefire covering the area of Lapul sub-county in Pader district so that the government delegation and LRA commanders could meet. However, to the peace talk never took place between the GoU and the LRA.

In 2004, there was another agreement between Sudan and Uganda for operation inside Sudan. This second military operation inflicted a heavy defeat on the LRA leading to capture of their senior commanders and rescue of some abducted children. In the same year Hon Bigombe once again engaged in an effort to bring an end the armed conflict in Northern Uganda. Bigombe gained the trust of the LRA leadership and the LRA appointed two senior commanders, Vincent Otti and Sam Kolo, as negotiators in the new initiative. The peace initiative stalled in 2005 when Vincent Kolo defected to the side of GoU. However, the ceasefire agreement between the LRA and GoU did not materialise with both sides blaming each other for the failure. This demonstrated acts of masculinities that led to the resumption of military campaign between the UPDF and the LRA. Nevertheless, resolution of the armed conflict through military means has not been successful, in part due to ineffective operations against the LRA and an apparent lack of will by the government to end the armed conflict through a negotiated settlement.

In October 2005, the International Criminal Court (ICC) issued arrest warrants for Joseph Kony and the other top LRA leaders. The arrest warrant later became the main stumbling block to the signing of the Comprehensive Peace Agreement (CPA) between GoU and the LRA. The peace talks in Juba between the LRA and GoU led by Riek Machar Teny, the Vice President of the Government of Southern Sudan (GoSS) made a remarkable progress and resulted in a formal Cessation of Hostilities $(\mathrm{CoH})$ agreement signed on $26^{\text {th }}$ August 2006. In October 2007, the LRA sent a delegation to Kampala for the first time to meet with senior Ugandan officials. The LRA delegation also went to northern Uganda to consult with mainly the Acholi and Lango communities who have suffered most during the armed conflict as the parties got closer to concluding the peace talks. In May 2008, Joseph Kony rejected to sign the peace agreement with the GoU, a decision that put an end to the Juba peace talks which lasted nearly two years.

Although a comprehensive peace agreement was not signed, the Juba peace talk has resulted into relative calm for northern Uganda. Thousands of the Acholi have left the IDPs and have since then moved to their villages. At the same time, hundreds of LRA have also returned to Uganda under the existing amnesty programme. However, the civil war has spilled into the Sudan, the Democratic Republic of Congo (DRC) and Central African Republic (CAR). In December 2008, combined forces from Uganda, DRC and GoSS launched a joint military attack on the LRA camp in Garamba called "Operation Lighting Thunder" designed to completely finish the LRA. Since then the LRA has stepped up its operations in DRC, Western Equatorial in Southern Sudan and the Central African Republic abducting and killing thousands of civilians.

\section{Transition to Peace and Post-conflict Reconstruction}

Following the signing of the Cessation of Hostilities $(\mathrm{CoH})$ between GoU and the LRA in 2006, there is relative peace and order in Northern Uganda. Gulu municipality is booming with new investments in infrastructure and service industry. In 2007, the office of the Prime Minister issued the IDP camp phase-out guidelines emphasising voluntary return 
and respect for the IDPs. Since then majority of the IDPs have now returned to their villages. The presence of foreign military personnel has created a sense of security in the region. In March 2009, a joint military exercise called "Natural Fire" which involved soldiers from Burundi, Kenya, Tanzania, Rwanda and Uganda was carried out to train deserter relief capabilities. For the local people, their presence and their participation in immunisation exercises is reassurance of security. The discovery of oil in Amuru district has also raised hope in Northern Uganda. The production of oil is expected to create jobs, infrastructural development and social services.

The GOU, formulated a development framework, Peace, Recovery and Development Plan for Northern Uganda (PRDP) as a strategy to eradicate poverty and improve the welfare of the people in the region. PRDP is a stabilisation plan which has disaggregated Northern Uganda from national sector plans and it is the framework for post-conflict recovery and development intervention. The implementation of the PRDP has just begun in 55 districts. This big number of districts is due to the recent creation of new districts and also inclusion of the disaster-prone aspect in the programme. Currently, the original 4 districts in Acholi sub region have been divided into 7 over the past 3 years. The creation of new districts is formally intended to bring services closer to the people. However, this development has been criticised by policy advocates and academics on the basis that it depletes resources and reduces the capacity of district administrations and officials.

The transition to peace and post-conflict reconstruction has continued to raise other problems that need to be addressed. The several years of forceful encampment has a severe impact on the communities in northern Uganda. While men have always been the beneficiaries where gender inequities exist, men in Northern Uganda are paying heavy costs for the general supremacy which ignored men's vulnerability. Despite the projection of women as the victims of the horrendous conflict, women's independence and selfconfidence has increased. Many women have moved out of their traditional roles in order to meet social and economic demands inflicted on them by the armed conflict. Many of the women have become heads of their household, provided for their families and participated in the management of the IDP camps. The harsh economic situation and lack of employment opportunities have forced some men to assert their power over women through use of violence. Frustration, anger and disillusionment have forced many of them to alcoholism and sometimes suicide.

Gender-based violence has intensified in Northern Uganda because of the socioeconomic upheavals resulting from re-integration, recovery and re-settlement processes. The IDPs returning to their ancestral homes found themselves caught up in land conflicts as many elders who had knowledge of land boundaries have either been killed or died during the many years of displacement. The desire to acquire large hectares of land for commercial purposes and the knowledge of the economic value of land has created tension among the returnees. The political overtones of land grabbing, planned large scale sugarcane production and discovery of oil at Amuru has fuelled suspicion that such investments may only benefit those outside the region. Other factors are the creation of new districts which have created border disputes as communities struggle to control resources across and along these new borders. Similarly, border disputes between Murchison National Game Park, National Forest Authorities and the surrounding district of Amuru, Gulu and Oyam is very disturbing. The major sources of the conflict are illegal hunting, tree cutting and settlement in forest reserves. These problems and others which 
themselves are not gender neutral need to feature more prominently in post-conflict reconstruction programmes in Northern Uganda.

\section{Conclusion and Recommendations}

The horrendous armed conflict in Northern Uganda has inflicted a heavy blow on women, men and their children. The humanitarian, political, economic and social crisis had their impact on the communities. Women, men and their children were killed, abducted, raped, displaced and forced to join the armed forces. The brutal armed conflict systematically destroyed physical, cultural, emotional, social and economic wellbeing of the entire communities. Northern Uganda and its people have been pushed to squalor, humiliation and despair. The deep seated anguish, fear and despair sometimes gave way to alcoholism, suicides, domestic violence, rape and HIV/AIDs which mainly affected women and children. The resilience of women amidst these difficulties and their relentless search for peaceful resolution to the conflict gave hope for the communities.

Nevertheless, masculinity has continued to see women and children as victims of the civil conflict in Northern Uganda. As victims, women and children have often been left out formal post-conflict reconstruction. The PRDP has not made specific reference to the different situations for women, men and children and more specifically the magnitude of female vulnerability, loss of masculine status and frustrations of displacement. Although there is a Women's Task Force (WTF) for gender responsiveness, gender issues have not featured prominently in PRDP work plans and programmes. The WTF lacks the capacity to ensure that women actively participate in the planning, implementation and monitoring and evaluation of the PRDP. The inability of the WTF to influence decision making to ensure conflict sensitive interventions and resource allocation to address women, men and children's needs in Northern Uganda is a big setback to engendering the PRDP. Although there are excuses that targeting women as a separate group in the post-conflict reconstruction programmes risks breaking the already stressed social relations and could aggravate incidences of domestic violence, there are no concrete cases to support such allegations.

Post-conflict reconstruction is a complex process which involves social identities, roles, relationships, institutions and social welfare of the affected communities. In Northern Uganda where massive dislocations and disruptions have dismantled the prevailing social structure, there is a need to redefine the social basis of the nation, as well as the local communities and households. The most serious consequence of women's absence in the official peace process is that they are deprived of a unique opportunity to include their particular views and concerns in the post-conflict reconstruction of Northern Uganda. Women's inclination to be included in the post-conflict development process is more than a simple demand for numeric representation proportional to women's presence. It is a demand based on the conviction that male driven post-conflict reconstruction is unlikely to reflect the women's specific interests. Efforts should be made to find ways to integrate women's experiences at grassroots level into the main exercise of post-conflict reconstruction.

Similarly, the PRDP has not addressed the issue of land conflicts arising from the return process. Although the Constitution of Republic of Uganda and National Land Policy outlaw any discrimination against women, the process of integrating the policy into 
law and its implementation is very slow. Women have not been fully integrated into land and property related decision making and inheritance. In the context of Northern Uganda, instituting women's task force in the PRDP is one of the ways of integrating women's concerns and interests in post-conflict development programmes. There is need to create avenues for settling women's land concerns in the post-conflict resettlement and reconstruction process. Women should be incorporated into the customary leadership to enable them to bring on board their experiences to strengthen customary land tenure and protect women's access and use of land in case of divorce and death of their husbands.

An analysis of the different roles of women and men in conflict can offer new perspectives in understanding the post-conflict reconstruction. Sustainable post-conflict reconstruction requires, among other things, contravening the behavioural logic of violent actors and preventing re-establishment of the old discordant social order. Empowerment programmes should address both the needs of women and the collapsing masculine power in order to resolve reoccurrence of domestic gender violence. There is need for the postconflict reconstruction programmes to address the already troubled relationships resulting from displacement as well as the adverse traumatic conditions in the conflict ravaged northern Uganda in general. Emphasis should be paid to widowhood, diminished masculinities, the precarious new position of women as breadwinners and child households. Lastly, gender audit of the PRDP with the aim of establishing financial resources allocated to women and men should ensure that budget tracking of the PRDP should provide pointers to address conflict sensitive development programmes.

\section{References}

Alison, Miranda (2007). Wartime Sexual Violence: Women's Human Rights and Questions of Masculinity. Review of International Studies, Issue 33, 75-90.

Amnesty International (1991). Uganda: Human rights Violations by the National Resistance Army, Brussels: Amnesty International.

Annan, Jeannie; Blattman, Christopher; Mazurana, Dyan \& Carlson, Khristopher (2009). Women and Girls at War: Wives, Mothers and Fighters in the Lord's Resistance Army, http://www.prio.no/sptrans/185286780/blattman-women@war.1009.pdf (Accessed on $14^{\text {th }}$ March 2011).

Atkinson, Ronald Raymond (2010). The Regionalisation of the Lord's Resistance Army, Lecture, The Nordic Africa Institute

Bainomugisha, Arthur \& Tumushabe Godber (2005). The Torturous Peace Process in Northern Uganda: An Analysis of Peace Initiatives and Prospects for a Settlement, MACOMBA Policy and Academic Research Series No. 1, 2005.

Barker, Gary \& Ricardo, Christine (2005). Young Men and the Construction of Masculinity in sub-Saharan Africa: Implications for HIV/AIDS, Conflict, and Violence. Social Development Papers: Conflict Prevention and Reconstruction. Paper No. 26. Washington DC: The World Bank.

Dolan, Gerald. Chris (2003). Collapsing Masculinities and Weak States: A Case Study of Northern Uganda. In Cleaver, F ed., Masculinity Matters: Men, Masculinities and Gender Relations in Development, London: Zed Books.

Enloe, Cynthia (2000). Maneuvers: The International Politics of Militarising Women's Lives. Berkeley: University of California Press. 
Gallimore, Rangira Béa (2008). Militarism, Ethnicity and Sexual Violence in the Rwandan Genocide, in Mama, Amina \& Okazawa-Rey, Margo ed., Feminist Africa 10 Militarism, Conflict and Women's Activism. Rondebosch: African Gender Institute, University of Cape Town.

Human Rights Watch (1997). The Scars of Death: Children Abducted by the Lord's Resistance Army's in Uganda. New York: Human Rights Watch.

Human Rights Watch (2003). Stolen Children: Abduction and Recruitment in Northern Uganda. New York: Human Rights Watch.

Hutchings, Kimberly (2007). Making Sense of Masculinity and War, Men and Masculinities June 2008 vol. 10 no. 4 389-404.

Integrated Regional Information Networks (2011). Uganda: Bleak Future for Former Female Fighters, http:// www. peacewomen. org/ news_article. php? id=3176 \& type=news (Assessed 14 ${ }^{\text {th }}$ March 2011).

International Crisis Group (2004). Northern Uganda: Understanding and Solving the Conflict, Brussels: International Crisis Group.

Jacobsen, P. Joyce (2006). Men's Issues in Development, in The Other Half of Gender, Washington, DC: The World Bank.

Lorentzen, A. Lois. \& Turpin, Jennifer (1998). The Women and War Reader. New York: New York University Press.

Mazurana, Dyan \& McKay, Susan (2003). Girls in Fighting Forces in Northern Uganda, Sierra Leone, and Mozambique: Policy and Programme Recommendations. http://unddr.org/docs/Girls_in_Fighting_Forces.pdf (accessed 14th March 2011).

Ministry Finance Planning and Economic Development (2000). Peace, Recovery and Development Plan (PRDP) for Northern Uganda, Kampala: Government of Uganda.

$\mathrm{MoH}$ (2005). Policy Recommendations Based on the Major Findings of the 2004-05 UNHSB Survey, Kampala: Government of Uganda.

MoH (2007). The National policy Guidelines on Post Exposure Prophlaxis for HIV, Hepatitis B and Hepatitis C, Kampala: Government of Uganda.

Nabukeera-Musoke, Harriet (2007). Responses to Sexual Crimes in Armed Conflict \& Post Conflict Situations: Isis-WICCE's Experience, Presented at the Seminar on Hidden War Crimes: Challenging Impunity on Sexual Violence against Women and Girls in Conflict, Hosted by Acord-Kenya 27-28 March, 2007, Silver Springs Hotel, Kenya.

Nyeko, Balam \& Lucima, Okello (2002). 'Profiles of the parties to the conflict'. In Lucima, Okello (Ed.) Protracted Conflict, Elusive Peace Initiatives to End the Violence in Northern Uganda, London: Conciliation Resources.

Ochieng, Ruth Ojiambo (2002). The Scars on their Minds and their Bodies the Battle Ground: Women's Roles in Post Conflict Reconstruction, the $19^{\text {th }}$ International Peace Research Conference. The IPRA, Korea.

Office of the Prime Minister (2004). The National Policy for Internally Displaced Persons. Kampala: Government of Uganda.

Ohlsson, Leif (2000). Livelihood Conflicts - Linking Poverty and Environment as causes of Conflict, Environmental Policy Unit, Stockholm: Sida.

O'Kadameri, Billie (2002). LRA/Government Negotiations 1993-94. ACCORD: International Review of Peace Initiatives 1(11): 34-41.

Okio, Florence (2008). War and sexual based violence in Northern Uganda Issue, 388http://pambazuka.org/en/category/comment/49418. 
Oywa, Rosalba (2002). Women's Contribution to Peacebuilding in Northern Uganda, ACCORD: An International Review of Peace Initiatives, Issue 11.

Refugee Law Project (2009). Gender against Men, Video Documentary: Kampala: Refugee Law Project.

Romaniuk, Scott Nicholas (2010). Rape Warfare: Sexual Violence as Systematic Weapon of War. American Journal of Scientific Research, Issue 9, 23-29.

Scott-Samuel, Alex (2009). Patriarchy, Masculinities and Health Inequalities. Journal Health Policy and Public Health, Gac Sanit. 23(2):159-160.

Silberschmidt, Margrethe (2007). Formations of Masculinity/Men and Gender in Africa. The Routledge International Encyclopaedia of Men and Masculinities. Vol. 1. Eds. M. Flood, J.K. Gardiner, B. Pease, and K. Pringle London: Routledge.

Sommers, Marc (2006). Fearing Africa's Young Men: Male Youth, Conflict, Urbanisation and the Case of Rwanda in the Other Half of Gender. Washington, DC: The World Bank.

Sweetman, Caroline (2005). Gender, Peacebuilding and Reconstruction. London: Oxfam Publication.

Theidon, Kimberly (2009). Reconstructing Masculinities: The Disarmament, Demobilisation and Reintegration of Former Combatants in Colombia. Human Rights Quarterly 31: 30.

Woodbury, Laura (2011). Reconstructing Gender Identity for Child Combatants in PostConflict African Societies. Journal of International Service. Volume 20, Number 1.

\section{Author Biography}

Senath Robert Esuruku (PhD) is the Head of Research, International Alert Uganda. Formerly, he was a visiting fellow at the Kellogg Institute, University of Notre Dame, United States and a lecturer at Uganda Martyrs University. His research interests focus on human rights, gender, good governance and development. Over the last ten years, he has published articles and modules on these areas and taught, supervised and examined postgraduate students registered at different universities in Africa, Europe and North America. 